\title{
Prof. dr hab. n. med. Maria Starzycka ur. 15 czerwca 1934 roku zm. 20 grudnia 2018 roku
}

\author{
„Śmierć przychodzi cicho. Niezapowiedziana, nieproszona. \\ Nigdy nie ma na nią odpowiedniej chwili, jest zawsze gościem nie na czas..."
}

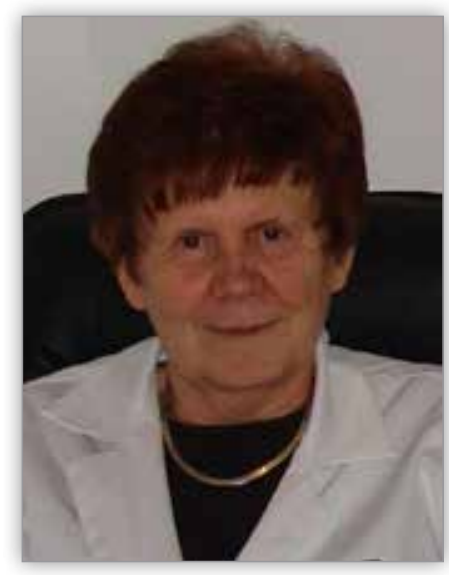

Tymi słowami, w dniu 27 grudnia 2018 roku na Cmentarzu Salwatorskim w Krakowie pożegnaliśmy śp. Panią Profesor Marię Starzycką. Pani Profesor urodzita się 15 czerwca 1934 roku w Krakowie. W 1951 roku zdała egzamin dojzałości w Gimnazjum im. Józefy Joteyko. W latach 1955-1961 studiowała na Wydziale Lekarskim Akademii Medycznej w Krakowie, uzyskując z wyróżnieniem dyplom lekarza medycyny. Całe życie zawodowe i kariera akademicka Pani Profesor były związane z Katedrą i Kliniką Okulistyki w Krakowie, gdzie rozpoczęła pracę w 1963 roku. Przez następne lata pracy i rozwoju zawodowego, zdobywała koleje stopnie naukowe: doktora nauk medycznych w 1969 roku na podstawie rozprawy zatytułowanej „Wyniki operacyjnego leczenia nowotworów złośliwych powiek u chorych leczonych w Klinice Chorób Oczu Akademii Medycznej w Krakowie w latach 1948-1967". Następnie w 1983 roku habilitowała się na podstawie rozprawy "Samoistne odwarstwienie siatkówki w świetle badań klinicznych i oznaczeń składników mineralnych i wolnych kwasów tłuszczowych w płynie podsiatkówkowym". W swojej pracy zastosowata nowoczesną metodę badania składu płynu podsiatkówkowego, jaką była atomowa spektrometria absorpcyjna, co było nowatorskim podejściem analitycznym, a praca stała się pionierską $w$ tej dziedzinie. W 1993 roku uzyskała tytut profesora nadzwyczajnego, a w 2000 profesora zwyczajnego.

Pani Profesor Maria Starzycka w latach 1996-2004 była kierownikiem Katedry i Kliniki Okulistyki Collegium Medicum Uniwersytetu Jagiellońskiego. W latach 1990-1993 i 1996-1999 petniła funkcję prodziekana Wydziału Lekarskiego. Aktywnie działała w Polskim Towarzystwie Okulistycznym. Zasiadała w Zarządzie Głównym Polskiego Towarzystwa Okulistycznego, dwie kadencje pełnita funkcję Przewodniczącej Krakowskiego Oddziału PTO oraz była wiceprzewodniczącą Sekcji Retinologicznej PTO. Przez ponad 10 lat była redaktorem naczelnym czasopisma naukowego "Klinika Oczna”. Została odznaczona Złotym Krzyżem Zasługi.

Pani Profesor była cztonkiem kilku okulistycznych towarzystw zagranicznych. Jako jedyna osoba z Polski po czteroletnim okresie kandydackim została przyjęta do kręgu członków elitarnego, szwajcarskiego Klubu Julesa Gonina, skupiającego liczących się retinologów z całego świata. Wielokrotnie odbywała kilkutygodniowe staże i szkolenia w renomowanych zagranicznych klinikach m.in. w Tybindze, Münster, Erlangen, Liverpoolu i w Bostonie.

Działalność naukowo-badawcza Pani Profesor dotyczyła przede wszystkim problematyki retinologicznej, obejmującej zagadnienia związane z pierwotnym, otworopochodnym odwarstwieniem siatkówki, dystrofiami siatkówki, retinopatią wcześniaków, czy ze zwyrodnieniem plamki związanym z wiekiem. W badaniach nad odwarstwieniem siatkówki opracowała szereg zagadnień dotyczących obrazu i przebiegu klinicznego, rokowania oraz metod i wyników leczenia. Zostały one opublikowane $w$ cyklu prac, w których zawarła zasady optymalizacji leczenia operacyjnego tego schorzenia. W ostatnim okresie swojej działalności naukowej Pani Profesor zajmowała się głównie problematyką diagnostyki i leczenia czerniaka naczyniówki z zastosowaniem brachyterapii. W monografii opublikowanej w 1998 roku p.t. "Czerniak złośliwy" jest autorem trzech rozdziatów dotyczących diagnostyki różnicowej, leczenia oraz rokowania w różnych postaciach klinicznych czerniaka gałki ocznej.

Owocem dużej aktywności naukowo-badawczej Pani Profesor były liczne publikacje polskie i zagraniczne, których zostawita po sobie ponad 100.

Pod kierunkiem Pani Profesor specjalizację z okulistyki uzyskało ponad 30 osób. Była promotorem 10 przewodów doktorskich $\mathrm{i}$ jednej habilitacji.

Pani Profesor Maria Starzycka była Człowiekiem wielkiego autorytetu, była wspaniałym lekarzem i okulistą, cieszącym się dużym uznaniem i szacunkiem w środowisku medycznym oraz wśród pacjentów. Była cierpliwym i wyrozumiałym Nauczycielem, osobą otwartą na ludzi, ciepłą i pełną empatii. Zawsze można było liczyć na jej pomoc i wsparcie, zarówno w trudnych sprawach zawodowych, jak i naszych prywatnych problemach życiowych. Pani Profesor była także osobą bardzo wymagającą i mobilizującą swoich asystentów do ciągtego rozwoju, doskonalenia się i odkrywania tajemnic nauki i wiedzy.

Śp. Pani Profesor Maria Starzycka na zawsze pozostanie w naszych sercach i pamięci.

dr hab. n. med. Agnieszka Kubicka-Trząska 